\title{
Ovarian superstimulation with FSH in Wagyu breed bovine donors impacts folicular dynamics but does not improve the amount of embryos
}

\author{
Superestimulação ovariana com FSH em doadoras bovinas da raça Wagyu impacta a dinâmica \\ folicular, mas não melhora a quantidade de embriões \\ La sobreestimulación ovárica con FSH en donantes bovinas Wagyu afecta la dinámica folicular, \\ pero no mejora el número de embriones
}

Received: 07/26/2021 | Reviewed: 07/31/2021 | Accept: 08/02/2021 | Published: 08/07/2021

Fabio Marcelo de Queiróz

ORCID: https://orcid.org/0000-0002-7811-1179 Universidade Cesumar, Brazil

E-mail: fabioqmartimaq@hotmail.com

Márcia Aparecida Andreazzi

ORCID: https://orcid.org/0000-0002-4663-3837 Universidade Cesumar, Brazil

E-mail: marcia.andreazzi@unicesumar.edu.br

Fábio Luiz Bim Cavalieri

ORCID: https://orcid.org/0000-0003-4246-6995

Universidade Cesumar, Brazil

E-mail: fabio.cavalieri.@unicesumar.edu.br

Isabele Picada Emanuelli

ORCID: https://orcid.org/0000-0002-1423-2748

Universidade Cesumar, Brazil

E-mail: isabele.emanuelli.@unicesumar.edu.br

Marcelo Marcondes Seneda

ORCID: https://orcid.org/0000-0002-5097-5119

Universidade Estadual de Londrina, Brasil

E-mail: marcelo.seneda@uel.br

Fábio Morotti

ORCID: https://orcid.org/0000-0003-4476-6449

Universidade Estadual de Londrina, Brasil E-mail: fabiomorotti@uel.br

Vinicius Eduardo Gargaro Silva ORCID: https://orcid.org/0000-0002-8153-3559 Universidade Cesumar, Brazil

E-mail: vinicius.gargaro@gmail.com

Danieli Aparecida Bobbo Moreski ORCID: https://orcid.org/0000-0001-8587-7917 Universidade Cesumar, Brazil E-mail: danielibobi@hotmail.com

Antonio Hugo Bezerra Colombo ORCID: https://orcid.org/0000-0002-4661-3406 Universidade Cesumar, Brazil

E-mail: colombobhantonio@gmail.com

\begin{abstract}
The increase of the world population generates the need to raise the production of food of vegetal and animal origin. In Brazil, livestock farming has evolved, demonstrating the important role of the country in the production of food. In this way, researchers of this productive chain have been looking for technologies related to production and reproduction, above all, to the use of reproduction biotechnologies, seeking to increase the production of different bovine breeds. Thus, the objective of this research was to investigate the efficacy of ovarian FSH super stimulation in bovine Wagyu oocyte donor females on follicular dynamics and in vitro embryo production. Twelve Wagyu animals, aged 12 to 24 months, randomly distributed in a crossover design were used in two groups: Group 1= animals not stimulated with FSH and Group 2= animals stimulated with FSH. The follicular, oocyte and embryonic variables were evaluated. It was observed that ovarian overstimulation in Wagyu oocyte donor cows with FSH improved the mean and large follicles but reduced the rate of oocyte recovery and, despite the best percentage of viable oocytes, there was no improvement in the amount of embryos produced in vitro.
\end{abstract}

Keywords: Follicular aspiration; Reproductive biotechnology; Blastocyst; Antral follicle. 


\section{Resumo}

O aumento da população mundial gera a necessidade de elevar a produção de alimentos de origem vegetal e animal. No Brasil, a pecuária tem evoluído, demonstrando o importante papel do país na produção de alimentos. Dessa forma, pesquisadores dessa cadeia produtiva têm buscado tecnologias relacionadas à produção e reprodução, sobretudo, ao uso de biotecnologias de reprodução, buscando aumentar a produção de diferentes raças bovinas. Assim, o objetivo desta pesquisa foi investigar a eficácia da superestimulação com FSH em fêmeas bovinas doadoras de ovócitos da raça Wagyu sobre a dinâmica folicular e a produção de embriões in vitro. Doze animais Wagyu, com idades entre 12 e 24 meses, distribuídos aleatoriamente em delineamento crossover foram utilizados em dois grupos: Grupo 1= animais não estimulados com FSH e Grupo 2= animais estimulados com FSH. Foram avaliadas as variáveis foliculares, oocitárias e embrionárias. Observou-se que a superestimulação ovariana com FSH em vacas Wagyu doadoras de oócitos aumentou o número de folículos médios e grandes, mas reduziu a taxa de recuperação de oócitos e, apesar da melhor porcentagem de oócitos viáveis, não houve melhora na quantidade de embriões produzidos in vitro.

Palavras-chave: Aspiração folicula; Biotecnologias de reprodução; Blastocisto; Folículo antral.

\section{Resumen}

El aumento de la población mundial crea la necesidad de incrementar la producción de alimentos de origen vegetal y animal. En Brasil, la ganadería ha evolucionado, lo que demuestra el importante papel del país en la producción de alimentos. Así, los investigadores de esta cadena productiva han estado buscando tecnologías relacionadas con la producción y la reproducción, sobre todo, el uso de biotecnologías de reproducción, buscando incrementar la producción de diferentes razas bovinas. Por lo tanto, el objetivo de esta investigación fue investigar la eficacia de la superestimulación de la FSH en hembras bovinas donantes de ovocitos Wagyu sobre la dinámica folicular y la producción de embriones in vitro. Se utilizaron doce animales Wagyu, de edades comprendidas entre 12 y 24 meses, distribuidos aleatoriamente en un diseño cruzado en dos grupos: Grupo 1 = animales no estimulados con FSH y Grupo 2 = animales estimulados con FSH. Se evaluaron variables foliculares, ovocitarias y embrionarias. Se observó que la superestimulación ovárica con FSH en vacas Wagyu donantes de ovocitos aumentó el número de folículos medianos y grandes, pero redujo la tasa de recuperación de ovocitos y, a pesar del mejor porcentaje de ovocitos viables, no hubo mejoría en el número de embriones producidos in vitro.

Palabra clave: Aspiración de folículos; Biotecnologías reproductivas; Blastocisto; Folículo antral.

\section{Introduction}

The United Nations Organization (UNO, 2017) estimates an increase in world population, reaching 8.6 billion people in 2030 and 9.8 billion in 2050. Therefore, to meet the global food need for the population by 2050 , there should be a $60 \%$ increase in production. In this way, researchers of several production chains, including beef, have studied technologies related to management, sanitation, nutrition and reproduction (Colombo et al., 2017; Cavalieri et al., 2019), seeking to increase the number of animals and / or the stocking rate of pastures, and thus increase the production of meat by area.

Animal reproduction biotechnologies can contribute positively to this scenario. With the advent of artificial insemination (AI), producers were able to use bulls with high genetic value, and with the development of superovulation (SOV) and embryo transfer (ET) schemes, cattle breeding may increase the number of calves from females of high genetic standard (Hasler, 2014). Ultrasound guided follicular aspiration has led to an increase in the number of gestations of animals with high genetic value. Also, studies evaluating several hormonal protocols have been developed to improve the reproductive indices of animals (Hasler, 2014).

A protocol that has been studied is the SOV using FSH (Follicle Stimulating Hormone) followed or not by coasting, which is a period of absence of FSH, in bovine donors, aiming to contribute even more to the in vitro production of embryos.

According to Vieira et al. (2014), treatments using stimulation with FSH can promote the development of multiple follicles in the ovaries and improve embryo yield in Holstein breeders and thus, make embryo production more effective in vitro (IVEP) by ovum pick-up (OPU). However, the results of the research differ on the use of FSH, with or without coasting, in the different subspecies (Bos taurus taurus and Bos taurus indicus) and breeds (Sartori et al., 2016).

Studies involving the beneficial effects of FSH superstimulation, such as the greater proportion of medium and large size follicles associated with the use and subsequent gonadotrophin (coasting) withdrawal, aiming to improve oocyte competence and increase gestation rate are fundamental, especially in Wagyu cattle whose research is scarce. 
Wagyu cattle include four Japanese breeds: Black, Brown, Shorthorn and Polled (Gotoh et al., 2018) and the Black breed has adapted in several regions of Brazil, presenting economic importance due to the good yield, production and commercialization of meat noble with extreme marbling. This breed presents positive production characteristics such as, medium size, sexual precocity, reaching sexual maturity in up to 11 months for females and males, good maternal ability and ease of delivery, longevity, hardiness and docile temperament (Uchida et al., 2002).

Thus, the objective of this research was to investigate the efficiency of ovarian FSH super stimulation in bovine Wagyu oocyte donor females on follicular dynamics and in vitro embryo production.

\section{Methodology}

The experiment was carried out at School Farm - BIOTEC, at the University Unicesumar, Maringá, Paraná, Brazil $\left(23^{\circ} 25^{\prime} \mathrm{S}, 51^{\circ} 57^{\prime} \mathrm{W}\right.$ and 550 meters altitude) between March and June 2018. The biotechniques used in this research were approved by the Committee on Ethics in the Use of Animals of the University Unicesumar, under protocol No 004/2018.3.

Twelve Wagyu females, aged 12 to 24 months, mean weight of $350 \mathrm{~kg}$, oocyte donors from a commercial program, with no abnormalities in the reproductive tract, as determined by gynecological and ultrasonographic examination, were used. The animals were kept in brachiaria pickets (Brachiaria brizantha cv MG-5), with mineral supplementation and water ad libitum, being submitted to hygienic-sanitary management adopted in the property.

The animals were randomly assigned to a crossover design in two groups:

Group 1 (G1): control - animals not stimulated with hormone $=$ the experimental protocol of the cows of the Group 1 was to define a D0, a random day of the cycle, based on the commercial routine, on Day 8 was performed the follicular aspiration, lavage, oocyte classification and in vitro maturation (IVM), in Day 9 in vitro fertilization (IVF) and in Day 10, in vitro culture (IVC) (Figure 1).

Group 2 (G2): FSH super-stimulation = the experimental protocol of Group 2 cows consisted of a random day of the cycle, based on the commercial routine, on follicular wave synchronization with transvaginal progesterone (P4) implantation (CIDR Zoetis, São Paulo, SP), application of $2.0 \mathrm{mg}$ of estradiol benzoate (ESTROGIN®, Biofarm, Jaboticabal, SP) + $2.0 \mathrm{mg}$ PGF2 $\alpha$ (LUTALYSE®, Zoetis, São Paulo, SP), and 72 hours after the introduction of the P4 implant, on days D4, D5 and D6 a superovulation protocol (SOV) with consecutive applications of intramuscular FSH (Pluset巴, Hertape Calier, Brazil), 170 IU/ day/ animal and, after 48 hours of the last application of FSH, on Day 8 the removal of the P4 implant, ultrasound guided follicular aspiration, lavage, oocyte classification and IVM was performed, followed by Day 9 IVF, and on Day 10, the IVC (Figure 1).

The definition of the application of three consecutive doses of FSH and the 48 hour interval was based on Blondin et al. (2002).

At the time of aspiration, the ovarian follicles were identified and the diameter $(\mathrm{mm})$ determined by ultrasound (ALOKA SSD-500) and classified by size into three categories: 3 to $5 \mathrm{~mm}$ (small follicles), 6 to $8 \mathrm{~mm}$ (mean follicles) and equal to or larger than $9 \mathrm{~mm}$ (large follicles) (Ferreira et al. 2004).

Ultrasound (ALOKA SSD-500®) with $5 \mathrm{mHz}$ microconvex transducer (UST 974-5) was used to perform the follicular aspiration procedure, adjusted to a specific follicular suction guide for the bovine reproductive system. A $20 \mathrm{G}$ needle connected to a $50 \mathrm{~mL}$ Falcon tube was used through an aspiration system (Cook VBOA 18L®). The vacuum pressure was obtained by means of a pump (Cook V-MAR 5000®), adjusted between 38 and $45 \mathrm{mmHg}$, allowing a flow of $12 \mathrm{~mL}$ of medium/minute. The oocytes were aspirated with a solution containing 2.0\% Bovine Fetal Serum (BFS) (Nutricell®, Campinas, SP, Brazil), 25 IU/mL sodium heparin and 98.0\% PBS (Nutricell@, Campinas, SP, Brazil). 
Figure 1. Experimental protocol of Group 1 - control - Day 8: follicular aspiration, lavage, oocyte classification and in vitro maturation; Day 9: in vitro fertilization; Day 10: in vitro cultivation. Experimental protocol of Group 2 - Superstimulation with FSH - D0: follicular wave synchronization with transvaginal P4 implant, application of 2.0mg of estradiol benzoate $+2.0 \mathrm{mg}$ PGF2 $\alpha$; D4, D5 and D6: superovulation protocol with FSH 170 IU/ day/ animal; D8: removal of the implant, ultrasound guided follicular aspiration, lavage and oocyte classification and in vitro maturation; D9: in vitro fertilization; D10: in vitro cultivation.

\section{GROUP 1: CONTROL}

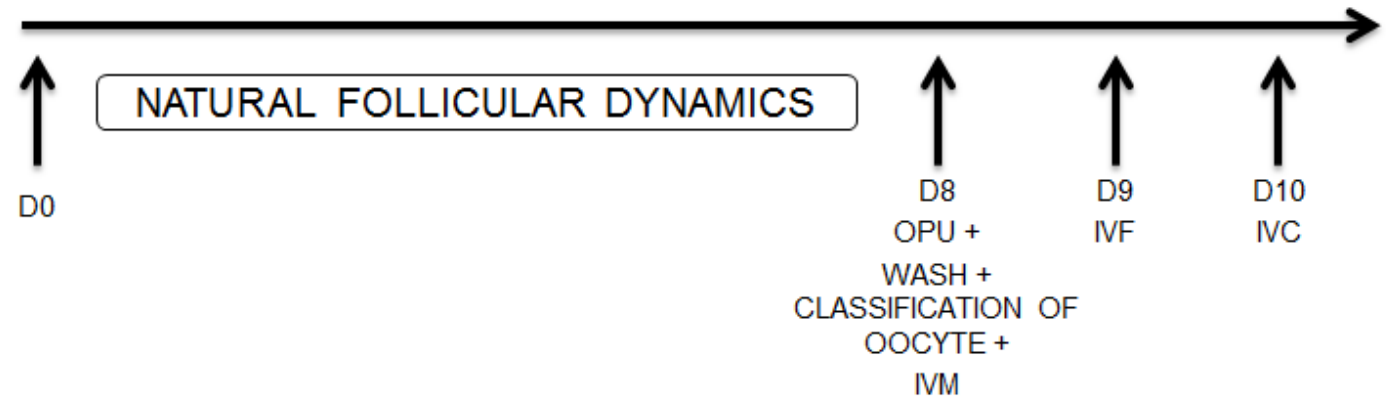

GROUP 2: OVER ESTIMULATION WITH FSH

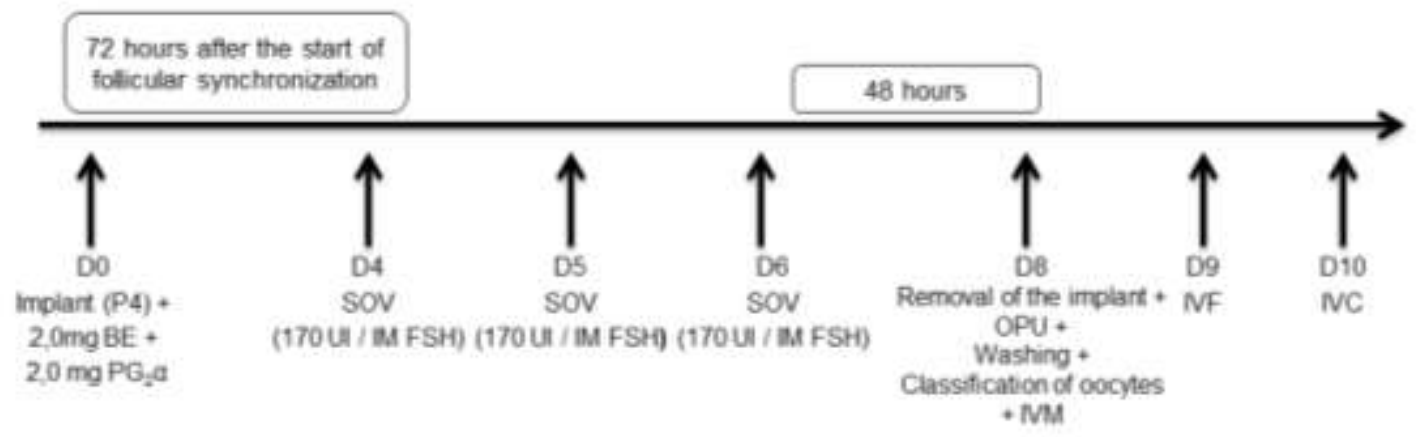

Source: Authors.

At the time of follicular aspiration, a low epidural anesthesia with $5 \mathrm{~mL}$ of $2 \%$ lidocaine (Pearson®, São Paulo/SP, Brazil) was performed to reduce peristaltic movements and discomfort in the animal. After administration of lidocaine, the animal had a vulva washed and cleaned with paper towel. The transducer was inserted into the vaginal sac and the manipulation of the ovaries through the rectum was performed to better visualize them on the ultrasound screen. The follicles were placed in the puncture line indicated on the ultrasound screen and aspirated, at random, not following order of size, through the needle and the vacuum pump, the same procedure was performed on all visible follicles in both ovaries. After aspiration the vacuum system was cleaned with the oocyte receiving medium and the used needles were discarded.

For washing and oocyte selection, the aspirated material was transferred to the embryo collection filter and washed with the same medium used for aspiration. The remaining sediments in the filter were transferred to Petri dish and the search, counting and classification of the oocytes as feasible and not viable. In the present study, the presence of cumulus and homogeneous cumulus and ooplasm were considered viable (grade I, II and III), those with heterogeneous and apoptotic vesicles were unfeasible (grade IV (De Loos et al., 1989).

IVM was performed on TCM199 with Earles salts (Gibco®), glutamine (Sigma® cod.:G8540) and NaHCO3 


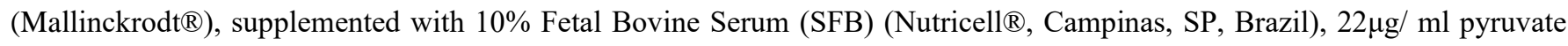

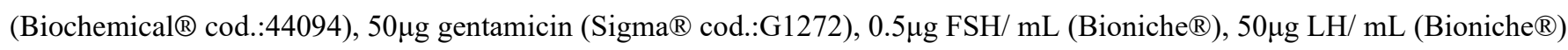
and $1 \mu \mathrm{g}$ estradiol $/ \mathrm{mL}$ (Sigma ${ }^{\circledR}$ cod.:E2758), kept in an oven at $39^{\circ} \mathrm{C}, 5 \% \mathrm{CO} 2$ in air at maximum humidity for $22-24$ hours. The oocytes were placed in $90 \mu \mathrm{L}$ microdrople of maturation medium covered with mineral oil.

After 22 to 24 hours, IVF was performed in $100 \mu \mathrm{L}$ of TALP medium supplemented with $10 \mu \mathrm{g} / \mathrm{mL}$ heparin (Sigma ${ }^{\circledR}$ cod.: H3149), $22 \mu \mathrm{L} / \mathrm{mL}$ pyruvate (Biochemical ${ }^{\circledR}$ cod.:44094), $50 \mu \mathrm{g} / \mathrm{mL}$ gentamicin (Sigma ${ }^{\circledR}$ cod.:G 1272), bovine serum albumin - BSA (no fatty acids) (Sigma ${ }^{\circledR}$ cod.:A3311), $2 \mu \mathrm{M}$ penicillin PHE solution (Sigma ${ }^{\circledR}$ cod.:P4875), $1 \mu \mathrm{M}$ hypotaurine (Sigma ${ }^{\circledR}$ cod.:H1384) and $0.25 \mu \mathrm{M}$ epinephrine (Sigma ${ }^{\circledR}$ cod.:E4250). Wagyu bull sexed semen was thawed in a $35^{\circ} \mathrm{C}$ water bath. For selection of the mobile spermatozoa and removal of diluents and seminal plasma, Percoll gradient centrifugation (90 and 45\%) was performed for 20 minutes. 1x106 spermatozoa / $\mathrm{mL}$ were used, and the oocytes were transferred to the droplets (20 oocytes/ drop), where they remained for 15 to 18 hours at $39^{\circ} \mathrm{C}$ in an atmosphere with $5 \% \mathrm{CO} 2$ in air.

After 15 hours of IVF, the zygotes were in vitro cultured (IVC) in SOF (Synthetic Oviduct Fluid) medium supplemented with SFB (Nutricell@, Campinas, SP, Brazil), incubated with a gas atmosphere containing $20 \% \mathrm{CO} 2$ in air, with maximum humidity.

After 48 hours of IVC, the cleavage rate was evaluated and the culture medium was renewed. In this period, when the cleavage occurred, the embryonary development with two, four and eight cells was observed.

The effect of FSH overestimation on the follicular, oocyte and embryonary variables was analyzed by the generalized linear model, including the main effect of the treatment (Super Stimulation with FSH vs. Control) and other sources of variation. In the presence of a significant effect, the means were compared by the Tukey's test. Differences in oocyte, viable oocyte and blastocyst recovery rates (FSH Super Stimulation vs. Control) were analyzed by the binary logistic regression model including the same treatment effect and sources of variation. In both models, all possible effects and interactions were considered. For descriptive analysis, the quantitative data are presented as mean (M) and standard error (SE) and qualitative data as percentage (\%). All statistical analyzes were performed in the Minitab ${ }^{\circledR}$ statistical program, version 18.1. The level of significance to reject $\mathrm{H} 0$ (the null hypothesis) was $5 \%$, so a level of significance $\leq 0.05$ was considered to indicate an effect of categorical variables and their interactions.

\section{Results and Discussion}

Based on the results obtained, it was observed that FSH over stimulation increased mean and large follicles $(\mathrm{p}<0.005)$ and, consequently, improved the total number of follicles (Table 1).

Corroborating our findings, Goodhand et al. (1999) also observed that the use of FSH increased the number and the mean diameter of the follicles available for puncture. In fact, Ribeiro et al. (2011) pointed out that hormonal over stimulation increases the number of follicles with adequate diameter for aspiration, that is, greater than $6 \mathrm{~mm}$.

However, despite this increase in the number of medium and large follicles, a reduction in oocyte recovery rate (81.0 vs $38.3 \%)(\mathrm{p}<0.0001)$ was observed. 
Table 1 - Effect of ovarian super stimulation with FSH on the number of small, medium and large follicles, ovum pick-up efficiency (OPU) and in vitro embryo production in Wagyu breeders.

\begin{tabular}{lccc}
\hline \multicolumn{1}{c}{ Variables } & $\begin{array}{c}\text { Group 1 } \\
(\mathbf{n = 1 2})\end{array}$ & $\begin{array}{c}\text { Group 2 } \\
(\mathbf{n = 1 2})\end{array}$ & P value \\
\hline Number of small follicles $(\mathrm{M} \pm \mathrm{SEM})$ & $16,2 \pm 1,5$ & $5,1 \pm 1,0$ & $<0,0001$ \\
Number of mean follicles (M $\pm \mathrm{SEM})$ & $4,4 \pm 0,6$ & $16,4 \pm 3,5$ & 0,017 \\
Number of large follicles (M $\pm \mathrm{SEM})$ & $1,0 \pm 0,5$ & $10,4 \pm 1,6$ & $<0,0001$ \\
Mean overall number of follicles (M $\pm \mathrm{SEM})$ & $21,6 \pm 1,9$ & $31,8 \pm 3,2$ & 0,013 \\
\hline Number of total oocytes $(\mathrm{M} \pm \mathrm{SEM})$ & $17,4 \pm 2,9$ & $12,2 \pm 2,5$ & 0,180 \\
Recovery rate $(\%, \mathrm{n} / \mathrm{N})$ & $81,0(192 / 237)$ & $38,3(134 / 350)$ & $<0,0001$ \\
Number of viable oocytes $(\mathrm{M} \pm \mathrm{SEM})$ & $13,0 \pm 2,3$ & $10,2 \pm 2,3$ & 0,232 \\
Percentage of viable oocytes $(\%, \mathrm{n} / \mathrm{N})$ & $74,5(143 / 192)$ & $83,6(112 / 134)$ & 0,047 \\
\hline Number of embryos $(\mathrm{M} \pm \mathrm{SEM})$ & $3,0 \pm 0,7$ & $2,4 \pm 0,6$ & 0,330 \\
\hline Blastocyst rate $(\%, \mathrm{n} / \mathrm{N})$ & $23,1(33 / 143)$ & $23,2(26 / 112)$ & 0,979 \\
\hline
\end{tabular}

$\mathrm{M} \pm \mathrm{SEM}$ : mean and more or less standard error of the mean; Group 1: control; Group 2: FSH over stimulation. Source: Authors.

Nevertheless, there are contradictory reports in the literature regarding recovery rate as a function of follicle size. Goodhand et al. (1999) found that although FSH increased the number and mean diameter of the available follicles for puncture, the number of oocytes recovered varied. Ribeiro et al. (2011) stated that hormonal overstimulation increases the number of follicles of adequate size for aspiration and recovery rate. Chagas et al. (2014) stated that small follicles present a lower rate of recovery compared to medium and large follicles. Ongaratto et al. (2015) worked with Brangus and Angus animals and found that the use of estradiol benzoate, progesterone to synchronize the follicular wave, PGF2 $\alpha$ to avoid the presence of corpus luteum and superovulation with FSH improved the number of oocyte cumulus complexes (COCs) recovered by OPU. Other studies (Blondin et al., 2002; Oliveira et al., 2016) reported that association between FSH and coasting eliminates small follicles and increases the quantity of medium and large follicles, facilitating aspiration.

However, it is emphasized that, these data diverge partially with the results of this study, because despite the larger size of the follicles, the recovery rate was lower. Similar to the findings of this study, Lonergan et al. (1994) also observed a lower recovery of oocytes in situations with a predominance of large follicles at the time of aspiration. The low recovery rate found in this study is attributed to race and losses in the abdominal cavity. Research shows that there are differences in the rate of recovery according to the species, showing that the protocols of follicular superovulation and aspiration in Bos indicus present better results, since they present a greater number of antral follicles and, consequently, a greater number of oocytes recovered when compared to the animals (Taurus et al., 1996), as is the case of the Wagyu breed of this study. However, the greater size of the follicles in OPU may result in a greater probability of loss of COCs in the peritoneal cavity or in greater difficulty in aspirating it, although Ribeiro et al. (2011) reported that it was easier to aspirate larger follicles because of better visualization on ultrasound.

The results also showed that FSH treatment improved the percentage of viable oocytes (74.5 vs $83.6 \%$ ). Regarding the number of total and viable oocytes recovered, Barbosa et al. (2013) observed the production of embryos in Nelore cows and reported that the mean number of oocytes aspirated ranged from 26.58 to 44.08. Silva et al. (2017) evaluated reproductive data from donors of Indian bovine breed oocytes and taurine submitted to ultrasonic guided follicular aspiration. The authors 
analyzed the field data of 734 follicular aspirations and observed a mean, among the races, of $31.85 \pm 16.65$ oocytes per aspiration, being $25.32 \pm 13.80$ viable, with emphasis on the largest number of oocytes aspirated and viable for donors of the Nellore breed, an Indian breed.

Thus, despite the superiority in the percentage of viable oocytes observed in the FSH treated group, the number of total oocytes (G1:17.4 $\pm 2.9, \mathrm{G} 2: 12.2 \pm 2.5)$ and (G1:13.0 \pm 2.3 ; G2:10.2 \pm 2.3$)$ obtained in this independent treatment study were lower than those reported in the literature for other races, especially Indian races, being in compliance with the (Table 1). In the present study, Bos indicus presented a higher number of oocytes recovered than Bos taurus (Sartori et al., 2016; Silva et al., 2017).

In addition, the results also showed that although FSH treatment improved the percentage of viable oocytes, there was no increase in the number of embryos, showing equivalent embryo production between the two groups evaluated (3.0 vs 2.4).

Unlike the findings of this research, Ribeiro et al. (2011) pointed out that hormonal overstimulation increases the number and size of follicles and increases the number of embryos. Baruselli et al. (2012) also reported an increase in PIVE in an experiment with Brangus and Angus donors treated with four equal doses of FSH, twice a day, initiated at the time of follicular wave emergence, and with OPU at 24 hours after the last FSH treatment. Other studies have shown that FSH over stimulation, associated with coasting, improves oocyte competence (Nivet et al., 2012), blastocyst and gestation rates (Labrecque et al., 2013), increases the efficiency of IVP and percentage of in vitro blastocyst development and number of embryos per OPU session (Vieira et al., 2014).

Therefore, even with the 48 hour interval between the last FSH application and the OPU used in this research and with the highest percentage of viable oocytes, it was not possible to increase the number of embryos.

It is thought that oocyte viability is only indicative of oocyte competence, based on its morphology, indicating the ability of the oocyte to ensure embryonic development after fertilization (Sirard, 1989). Furthermore, it is known that in the in vivo production of bovine embryos, approximately $80 \%$ of ovulated oocytes develop to blastocyst, whereas in PIVE, only $40 \%$ reach this stage (Lonergan; Fair, 2008). Researchers (Rizos et al., 2002; Bertagnolli et al., 2004) show that the in vitro maturation (IVM) environment influences this low rate. Experiments have found that oocytes obtained from in vivo maturation after stimulation with FSH and GnRH are more competent to develop blastocysts than in vitro maturates (Van De Leemput et al., 1999; Humblot et al., 2005), suggesting that that IVM should determine suboptimal conditions for the development of immature oocytes (Pereira et al., 2010).

\section{Conclusion}

Ovarian overstimulation in Wagyu oocyte donor cows with FSH improved the mean and large follicles but reduced the rate of oocyte recovery and, despite the best percentage of viable oocytes, there was no improvement in the number of embryos produced in vitro.

\section{References}

Barbosa, C. P., Toniollo, G. H. \& Guimarães, E. C. (2013). In vitro production of nelore bovine embryos originated from oocytes from ovaries with and without corpus luteum. Ciência Animal Brasileira. 14:81-90. <https://doi.org/10.5216/cab.v14i1.12588>

Baruselli, P. S., Sá Filho, M. F., Ferreira, R. M., Sales, J. N. D., Gimenes, L. U., Vieira, L. M. \& Bó, G. A. (2012). Manipulation of follicle development to ensure optimal oocyte quality and conception rates in cattle. Reproduction in Domestic Animals. 47:134-141. <https://doi.org/10.1111/j.14390531.2012.02067.x>

Blondin, P., Bousquet, D., Twagiramungu, H., Barnes, F. \& Sirard, M. (2002). A manipulation of follicular development to produce developmentally competent bovine oocytes. Biology of Reproduction. 66:38-43. <https://doi.org/10.1095/biolreprod66.1.38>

Blondin, P., Vigneault, C., Nivet, A. L., \& Sirard, M. A. (2012). Improving oocyte quality in cows and heifers - What have we learned so far? Animal Reproduction, 9: 281-289. 
Cavalieri, F. L. B., Burali, P. H. B., Morotti, F., Seneda, M. M., Andreazzi, M. A. \& Colombo, A. H. B. (2019). Effects of a reusable progesterone device on conception rates and estrus cycle re-synchronization in Nelore cows. Semina: Ciências Agrárias. 40:3540. <http://dx.doi.org/10.5433/16790359.2019v40n6Supl3p3501>

Colombo, A. H. B., Cavalieri, F. L. B., Andreazzi, M. A., Moreski, D. A. B., Botelho, A. C. F. A. \& Santos, J. M. G. (2017). Evaluation of biotechnics of reproduction under the environmental focus. Archives of Veterinary Science. 22:81-89. <http://dx.doi.org/10.5380/avs.v22i1.50814>

de Loos, F., van Vliet, C., van Maurik, P. \& Kurip, T.A. (1989). Morphology of immature bovine oocytes. Gamete Research. 24:197-204. $<$ https://doi.org/10.1002/mrd.1120240207>

Ferreira, A. M., Viana, J. H. M., Camargo, L. S. A., Sá, W. F. \& Pereira, P. A. C. (2004). Ovarian follicular population during estrous cycle in Gir breed (Bos indicus) cows. Revista Brasileira de Zootecnia. 33:1689-1694. <https://doi.org/10.1590/S1516-35982004000700007>

Goodhand, K. L., Watt, R. G., Staines, M. E., Hutchinson, J. S. \& Broadbent, P. J. (1999). In vivo recovery and in vitro embryo production from bovine donors aspirated at different frequencies or following FSH treatment. Theriogenology. 51:951-961. <https://doi.org/10.1016/S0093-691X(99)00041-2>

Gotoh, T., Nishimura, T., Kuchida, K. \& Mannen, H. (2018). The Japanese Wagyu beef industry: current situation and future prospects: A review. Asian Australasian Journal of Animal Sciences. 31:933-950. <https://doi.org/10.5713/ajas.18.0333>

Hasler, J. F. (2014). Forty years of embryo transfer in cattle: A review focusing on the journal Theriogenology, the growth of the industry in North America, and personal reminisces. Theriogenology. 81:152-169. <https://doi.org/10.1016/j.theriogenology.2013.09.010>

Labrecque, R., Vigneault, C., Blondin, P. \& Sirard, M. A. (2013). Gene expression analysis of bovine oocytes with high developmental competence obtained from FSH-stimulated animals. Molecular Reproduction and Development. 80:428-440. <https://doi.org/10.1002/mrd.22177>

Lonergan, P., Monaghan, P., Rizos, D., Boland, M. P. \& Gordon, I. (1994). Effect of follicle size on bovine oocyte quality and developmental competence following maturation, fertilization, and culture in vitro. Molecular Reproduction and Development. 37:48-53. <https://doi.org/10.1002/mrd.1080370107>

Nivet, A. N., Bunel, A., Labrecque, R., Belanger, J., Vigneault, C., Blondin, P. \& Sirard, M. A. (2012). FSH withdrawal improves developmental competence of oocytes in the bovine model. Reproduction. 143:165-171. <https://doi.org/10.1530/REP-11-0391>

Ongaratto, F. L., Villamil, P. R., Tribulo, A. \& Bó, G. A. (2015). Effect of follicle wave synchronization and gonadotropin treatments on the number and quality of cumulus-oocyte complex obtained by ultrasound-guided ovum pick-up in beef cattle. Animal Reproduction. 12:876-883.

United Nation Organization - UNO/ BRASIL. FAO: Se o atual ritmo de consumo continuar, em 2050 o mundo precisará de $60 \%$ mais alimentos e $40 \%$ mais água.

Pereira, M. M., Costa, F. Q., Oliveira, A. P., Serapião, R. V., Machado, M. A., Viana, J. H. M. \& Camargo, L. S. A. (2010). Quantification of maternal transcripts in bovine oocytes under different maturation systems. Arquivo Brasileiro de Medicina Veterinária e Zootecnia. 62:1394-1400. $<$ https://doi.org/10.1590/S0102-09352010000600015>

Ribeiro, L. V. P., Rigolon, L. P., Cavalieri, F. L. B., Seko, M. B., Martinez, A. C., Ribeiro, M. G., Martins, R. R., Ávila, M. R., \& De Conti, J. B. (2011). Oocyte recovery and in vitro production from cows stimulated with either FSH or ECG. Archivos de Zootecnia. 60:1021-1029.

Sartori, R., Gimenes, L. U., Monteiro Jr, P. L., Melo, L. F., Baruselli, P. S. \& Bastos, M. R. (2016). Metabolic and endocrine differences between Bos taurus and Bos indicus females that impact the interaction of nutrition with reproduction. Theriogenology. 86:32-40. <https://doi.org/10.1016/j.theriogenology.2016.04.016>

Uchida, H., Kobayasi, J., Inoue, T., Suzuki, K. \& Oikawa, T. (2002). Current level of reproductive performances in Japanese Black cows. Asian Australasian Journal of Animal Sciences. 15:1098-1102. <https://doi.org/10.5713/ajas.2002.1098>

Vieira, L. M., Rodrigues, C. A., Castro Netto, A., Guerreiro, B. M., Silveira, C. R. A., Moreira, R. J. C., Sá Filho, M. F., Bó, G. A., Mapletoft, P. S. \& Baruselli, O. S. (2014). Superstimulation prior to the ovum pick-up to improve in vitro embryo production in lactating and non-lactating Holstein cows. Theriogenology. 82:318-324. <https://doi.org/10.1016/j.theriogenology.2014.04.013> 